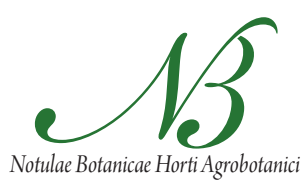

Cluj-Napoca

\title{
The Effects of Silver Nitrate Applications on the Flower Quantity of Cucumbers (Cucumis sativus L.)
}

\author{
Deniz KARAKAYA', Hüseyin PADEM² \\ ${ }^{1}$ Suleyman Demirel University, Isparta, Turkey; denizaceae@gmail.com \\ ${ }^{2}$ International Burch University, Francuske revolucije bb., Ilidža 71210 Sarajevo, Bosnia and Herzegovina
}

\begin{abstract}
This study was conducted to investigate the effects of silver nitrate $\left(\mathrm{AgNO}_{3}\right)$ on the flower quantity of cucumbers. The seeds used in this study, which was carried out in a plastic greenhouse, in the Gazi village of Antalya Province (Turkey) the during spring and autumn 2005 breeding periods, were 'Mostar F' (designated as 'GND1') and 'Vesco Seeds Beith Alpha $\mathrm{F}_{1}\left(26.50 \mathrm{~F}_{1}\right)$ ', designated as 'GND2' and those are the types having common production. The silver nitrate application was performed by the method of spraying on the growth tips of plants and 0,250,500,750, and $1000 \mathrm{ppm}$ silver nitrate doses were administered. The research was conducted with 4 repetitions having 5 plants in each repetition according to the Random Parcel Trial Pattern. In order to determine the effects of the applications, the effects of a number of female flowers and male flowers on generative characteristics of planting periods (spring and fall) were identified and the results were statistically evaluated. According to the results obtained in this research, $\mathrm{AgNO}_{3}$ has led to the formation of male flowers (no male flower formation in control), has increased the number of male flowers, and has led to a decrease in the number of female flowers. The increase in the number of male flowers varied according to the periods (in 'GND2').
\end{abstract}

Keywords: Cucumis sativus L., female flowers, male flowers, silver nitrate

\section{Introduction}

Until recent years, Turkey was dependent on foreign countries in terms of seeds as the initial cultivation material both in open and under cover vegetable breeding. Recently, the growing number of Turkish rehabilitation companies has reduced this dependency and many organizations were also encouraged to work on this issue. The operations in many of the rehabilitation companies are in the form of either bringing in the parent lines here from abroad and the production of their hybrids or the performance of their adaptation trials or taking out just a few generations here. A full rehabilitation program still cannot be executed by many companies. Our country is suitable for rehabilitation studies ecologically and in terms of genetic resources; our own seed needs should be ensured through planning many rehabilitation programs and we could even export the seeds to foreign countries (Şensoy, 2004).

In almost all commercial cucumber growing fields in the world, the gynoecious and monoecious kinds are used. With these kinds, efficiency is directly proportional to the number of female flowers. However, the ecological factors such as light intensity, light duration and temperature can affect the generative structure of cucumbers. For example, while the high temperatures and long days in the cultivation period increase the number of male flowers of cucumbers, they lead to the reduction of the number of female flowers, and hence cause the degradation of efficiency (Cantliffe, 1981).
In the cucumber plants, there are forms of flowers: andromonoecious (the male flowers and the form of male flowers that were transformed into the hermaphrodite flowers), gynomonoecious (the female flowers and the female flowers that were transformed into the hermaphrodite flowers), trimonoecious (the male flowers, female flowers and hermaphrodite flowers), gynomonodioecious (the monoecious and gynoecious flowering plants in a population), gynodioecious (the female and hermaphrodite flowering plants in a population) and androdioecious (the male and hermaphrodite flowering plants in a population), in addition to the monoecious (monecious), androecious (male flowers) and gynoecious (female flowers) flowers (Vural et al., 2000).

The sex appearance of cucumbers is closely connected to their genetic and environmental conditions (Apan, 1974). As a matter of fact, the cucumber plants have been put under stress from changing the environmental conditions of plants and we have attempted to measure changes in their gender appearance in this study.

There are some strict rules to be complied both by the rehabilitator companies developing the seed varieties and as well as the production companies developing the production in the seed breeding business. Among these, protecting the purity of these varieties is an important issue. The rehabilitator must maintain the sustainability of the rehabilitation program to help protect the characteristics of developed varieties. The persons who perform the seed production are required to timely implement primarily the isolation distance, combating and culturing processes, 
140

and to properly apply the applications (Frankel and Glun, 1977). For this reason, this research focuses only on the sex appearance of individual cucumbers obtained as a result of rehabilitation programs affected by the applications, with untouched desired characteristics.

The Cucurbitaceae family is a group of vegetables having rather different characteristics from other vegetable families in terms of its fertilization characteristics. Within this group, the Cucumis sativus L. (cucumber) species have very variable flower profiles on the basis of types. Some varieties can engender only female flowers, some can engender female and male flowers, or hermaphrodite flowers together with some other types of flowers. In Turkey in the greenhouse cucumber breeding, the varieties with female flowers are much more preferred due to the parthenocarpic (without pollination and fertilization; those that can bear fruit without needing the male flowers) characteristics of the plant and almost all the used cucumber varieties are constituted from $F_{1}$ hybrid varieties. However, the engendering of male and female flowers in parent plants that will be used for the rehabilitation of hybrid varieties is an important problem. This is because almost all $F_{1}$ hybrid varieties on the market are parthenocarpic, as also requested in their registrations by the ministry, and surely those do not have male flowers. When the need arose to use them as a source of pollen as a parent plant with a female flower, the engendering of male flowers was attempted by applying different chemicals on those plants. $\mathrm{AgNO}_{3}$ (silver nitrate) is one of these chemicals used in almost every area in agriculture for many important issues, such as to control plant growth and development, to obtain good yields from the plants, to organize the fruit bearing, to ensure a well-developed plant, to get flowers before their time, to delay flowering, to shorten dormant seasons, and to increase flowering, etc. In this study, it was intended to exhibit the effects of different doses of $\mathrm{AgNO}_{3}$ applications on the gender formation of the cucumber species, to boost male flower formation; to identify which level of silver nitrate application would best boost the formation of male flowers, and to develop practical recommendations on these issues.

\section{Materials and methods}

This study was carried out in the iron skeleton plastic greenhouse having a North-South direction at Bircan Tarim Turizm Tic. Ith. Ihr. ve San. Ltd. Şti. (Turkey), with dimensions of $42 \mathrm{~m}$ in width, a length of $54 \mathrm{~m}$, a side height of $2.5 \mathrm{~m}$, and a roof height of $4 \mathrm{~m}$, in the Gazi village of Antalya Province during the spring and autumn 2005 breeding periods.

The seeds used in the trial were 'Mostar $\mathrm{F}_{1}$ ' belonging to Bircan Tarim Turizm Tic. Ith. Ihr. ve San. Ltd. Şti. and 'Vesco Seeds Beith Alpha $\mathrm{F}_{1}\left(26.50 \mathrm{~F}_{1}\right.$ )' belonging to $\mathrm{Su}$ Tarim Tic. Ltd. Şti. Those are the types having common production.
In the study, the production method with seedlings was preferred. This meant that the first the seedlings were obtained then switched to the production phase. A 3:1 ratio mixture of peat and perlite was used as the seedlings' soil mortar. The seedlings were grown in vials and $54(9 \times 6)$ sized vials were used for this purpose.

Among the used seed types, 'Mostar $\mathrm{F}_{1}$ ' belonging to Bircan Tarim Turizm Tic. Ith. Ihr. ve San. Ltd. Şti., was designated as 'GND1' and 'Vesco Seeds Beith Alpha $F_{1}$ ' (26.50 F 1 )', belonging to Su Tarim Tic. Ltd. Şti., were designated as 'GND2' to provide convenience and practicality in practice.

The silver nitrate application was performed by the method of spraying on the growth tips of plants and 250, 500, 750, and $1000 \mathrm{ppm}$ silver nitrate doses were administered. Also, the $\mathrm{AgNO}_{3}$ application was conducted early in the morning (before sunrise) to avoid the sunburn of the plants. The irrigation was conducted in the form of drip irrigation and the necessary fertilization was applied in the form of fertigation.

\section{Results}

The obtained data was assessed according to the method of two-factor change analysis, which contains two factors: the amount of silver nitrate and the plantation season. The differences between applications were decided on the basis of the Duncan multiple comparison test $(\mathrm{P}<0.01)$, according to importance at the 0.01 level. The statistical analyses were conducted with the SPSS 13.0 package program. No comparisons of types have been performed.

\section{The Effects of $\mathrm{AgNO}_{3}$ on the number of male flowers}

The male flowers were observed only in $\mathrm{AgNO}_{3}$ applied plants during both the spring and fall seasons.

It was determined that the number of male flowers also increased depending on the increased $\mathrm{AgNO}_{3}$ doses applied on the 'GND1' variety in the spring season, and the differences between those increases were determined to be statistically significant at the $1 \%$ level (Tab. 1).

The $\mathrm{AgNO}_{3}$ applications increased the number of male flowers on the 'GND1' variety in the spring at a statistically significant level $(\mathrm{P}<0.01)$ (Tab. 2$)$.

Tab. 1. The number of male flowers of the $\mathrm{AgNO}_{3}$ applied 'GND1' variety in the spring season

\begin{tabular}{ccccccc}
\hline $\begin{array}{c}\text { The applied } \\
\text { silver nitrate } \\
\text { amounts } \\
(\mathrm{ppm})\end{array}$ & $\begin{array}{c}20 \\
\text { May }\end{array}$ & $\begin{array}{c}27 \\
\text { May }\end{array}$ & $\begin{array}{c}03 \\
\text { June }\end{array}$ & $\begin{array}{c}26 \\
\text { June }\end{array}$ & $\begin{array}{c}03 \\
\text { July }\end{array}$ & $\begin{array}{c}10 \\
\text { July }\end{array}$ \\
\hline $0 \mathrm{ppm}$ & $0.00 \mathrm{~d}^{*}$ & $0.00 \mathrm{e}$ & $0.00 \mathrm{e}$ & $0.00 \mathrm{e}$ & $0.00 \mathrm{e}$ & $0.00 \mathrm{e}$ \\
\hline $250 \mathrm{ppm}$ & $5.96 \mathrm{c}$ & $12.88 \mathrm{~d}$ & $16.46 \mathrm{~d}$ & $19.58 \mathrm{~d}$ & $27.92 \mathrm{~d}$ & $37.54 \mathrm{~d}$ \\
$500 \mathrm{ppm}$ & $13.71 \mathrm{~b}$ & $37.46 \mathrm{c}$ & $42.54 \mathrm{c}$ & $50.04 \mathrm{c}$ & $64.21 \mathrm{c}$ & $79.75 \mathrm{c}$ \\
\hline $750 \mathrm{ppm}$ & $14.67 \mathrm{~b}$ & $72.88 \mathrm{~b}$ & $81.04 \mathrm{~b}$ & $90.04 \mathrm{~b}$ & $113.25 \mathrm{~b}$ & $133.92 \mathrm{~b}$ \\
$1000 \mathrm{ppm}$ & $17.25 \mathrm{a}$ & $82.92 \mathrm{a}$ & $94.38 \mathrm{a}$ & $111.67 \mathrm{a}$ & $147.67 \mathrm{a}$ & $178.54 \mathrm{a}$ \\
\hline
\end{tabular}

${ }^{*}$ The differences between values shown with different letters are statistically significant (Duncan multiple comparison test $\mathrm{P}<0.01$ ). 
Tab. 2. The number of male flowers of the $\mathrm{AgNO}_{3}$ applied 'GND2' variety in the spring season

\begin{tabular}{ccccccc}
\hline $\begin{array}{c}\text { The applied } \\
\text { silver nitrate } \\
\text { amounts }(\mathrm{ppm})\end{array}$ & $\begin{array}{c}20 \\
\text { May }\end{array}$ & $\begin{array}{c}27 \\
\text { May }\end{array}$ & $\begin{array}{c}03 \\
\text { June }\end{array}$ & $\begin{array}{c}26 \\
\text { June }\end{array}$ & $\begin{array}{c}03 \\
\text { July }\end{array}$ & $\begin{array}{c}10 \\
\text { July }\end{array}$ \\
\hline $0 \mathrm{ppm}$ & $0.00 \mathrm{~d}^{*}$ & $0.00 \mathrm{e}$ & $0.00 \mathrm{e}$ & $0.00 \mathrm{e}$ & $0.00 \mathrm{e}$ & $0.00 \mathrm{e}$ \\
$250 \mathrm{ppm}$ & $6.46 \mathrm{c}$ & $10.13 \mathrm{~d}$ & $11.42 \mathrm{~d}$ & $13.33 \mathrm{~d}$ & $16.00 \mathrm{~d}$ & $18.29 \mathrm{~d}$ \\
$500 \mathrm{ppm}$ & $6.92 \mathrm{c}$ & $12.46 \mathrm{c}$ & $14.54 \mathrm{c}$ & $19.50 \mathrm{c}$ & $25.17 \mathrm{c}$ & $29.04 \mathrm{c}$ \\
$750 \mathrm{ppm}$ & $8.33 \mathrm{~b}$ & $17.29 \mathrm{~b}$ & $22.46 \mathrm{~b}$ & $28.13 \mathrm{~b}$ & $42.42 \mathrm{~b}$ & $52.79 \mathrm{~b}$ \\
$1000 \mathrm{ppm}$ & $12.75 \mathrm{a}$ & $26.79 \mathrm{a}$ & $34.08 \mathrm{a}$ & $42.58 \mathrm{a}$ & $61.59 \mathrm{a}$ & $78.13 \mathrm{a}$ \\
\hline
\end{tabular}

Tab. 3. The number of male flowers of the $\mathrm{AgNO}_{3}$ applied 'GND1' variety in the fall season

\begin{tabular}{|c|c|c|c|c|c|c|}
\hline $\begin{array}{l}\text { The applied } \\
\text { silver nitrate } \\
\text { amounts } \\
\text { (ppm) }\end{array}$ & $\begin{array}{c}22 \\
\text { Oct }\end{array}$ & $\begin{array}{l}29 \\
\text { Oct }\end{array}$ & $\begin{array}{l}05 \\
\mathrm{Nov}\end{array}$ & $\begin{array}{c}28 \\
\text { Nov }\end{array}$ & $\begin{array}{c}05 \\
\text { Dec }\end{array}$ & $\begin{array}{c}12 \\
\text { Dec }\end{array}$ \\
\hline $0 \mathrm{ppm}$ & $0.00 \mathrm{e}^{*}$ & $0.00 \mathrm{e}$ & $0.00 \mathrm{~d}$ & $0.00 \mathrm{e}$ & $0.00 \mathrm{e}$ & $0.00 \mathrm{e}$ \\
\hline $250 \mathrm{ppm}$ & $10.25 \mathrm{~d}$ & $21.46 \mathrm{~d}$ & $30.04 \mathrm{~cd}$ & $35.67 \mathrm{~d}$ & $48.00 \mathrm{~d}$ & $60.63 \mathrm{~d}$ \\
\hline & $16.58 \mathrm{c}$ & $42.67 \mathrm{c}$ & & $62.42 \mathrm{c}$ & $80.59 \mathrm{c}$ & $99.13 c$ \\
\hline & & & & & & \\
\hline $1000 \mathrm{ppm}$ & & & & & & \\
\hline \multicolumn{7}{|c|}{$\begin{array}{l}\text { * The differences between values shown with different letters are statistically } \\
\text { significant (Duncan multiple comparison test } \mathrm{P}<0.01 \text { ) }\end{array}$} \\
\hline \multicolumn{7}{|c|}{$\begin{array}{l}\text { Tab. 4. The number of male flowers of the } \mathrm{AgNO}_{3} \text { applied } \\
\text { 'GND2' variety in the fall season }\end{array}$} \\
\hline $\begin{array}{l}\text { The applied } \\
\text { silver nitrate } \\
\text { amounts } \\
(\mathrm{ppm})\end{array}$ & $\begin{array}{l}22 \\
\text { Oct }\end{array}$ & $\begin{array}{l}29 \\
\text { Oct }\end{array}$ & $\begin{array}{c}05 \\
\text { Nov }\end{array}$ & $\begin{array}{c}28 \\
\text { Nov }\end{array}$ & $\begin{array}{c}05 \\
\text { Dec }\end{array}$ & $\begin{array}{c}12 \\
\text { Dec }\end{array}$ \\
\hline $0 \mathrm{ppm}$ & $0.00 \mathrm{~d}^{*}$ & $0.00 \mathrm{e}$ & 0.00 & $0.00 \mathrm{e}$ & $0.00 \mathrm{e}$ & $0.00 \mathrm{e}$ \\
\hline $250 \mathrm{ppm}$ & $8.13 c$ & $13.67 \mathrm{~d}$ & $17.63 \mathrm{~d}$ & $21.54 \mathrm{~d}$ & $25.21 \mathrm{~d}$ & $28.21 \mathrm{~d}$ \\
\hline $500 \mathrm{ppm}$ & $9.00 \mathrm{c}$ & $16.63 c$ & $21.71 \mathrm{c}$ & $28.67 c$ & $36.25 c$ & $41.13 c$ \\
\hline $750 \mathrm{ppm}$ & $11.25 \mathrm{~b}$ & $22.96 \mathrm{~b}$ & $32.38 \mathrm{~b}$ & $40.04 \mathrm{~b}$ & $57.59 \mathrm{~b}$ & $69.83 \mathrm{~b}$ \\
\hline $1000 \mathrm{ppm}$ & $15.75 \mathrm{a}$ & $36.25 \mathrm{a}$ & $47.17 \mathrm{a}$ & $58.67 \mathrm{a}$ & $82.25 \mathrm{a}$ & $101.79 \mathrm{a}$ \\
\hline
\end{tabular}

${ }^{*}$ The differences between values shown with different letters are statistically significant (Duncan multiple comparison test $\mathrm{P}<0.01$ )

Tab. 5. The number of female flowers of the $\mathrm{AgNO}_{3}$ applied 'GND1' variety in the spring season

\begin{tabular}{lcccccc}
\hline $\begin{array}{c}\text { The applied } \\
\text { silver nitrate } \\
\text { amounts } \\
\text { (ppm) }\end{array}$ & $\begin{array}{c}20 \\
\text { May }\end{array}$ & $\begin{array}{c}27 \\
\text { May }\end{array}$ & $\begin{array}{c}03 \\
\text { June }\end{array}$ & $\begin{array}{c}26 \\
\text { June }\end{array}$ & $\begin{array}{c}03 \\
\text { July }\end{array}$ & $\begin{array}{c}10 \\
\text { July }\end{array}$ \\
\hline $0 \mathrm{ppm}$ & $10.92 \mathrm{a}$ & $12.83 \mathrm{a}$ & $14.83 \mathrm{a}$ & $18.58 \mathrm{a}$ & $20.83 \mathrm{a}$ & $22.83 \mathrm{a}$ \\
$250 \mathrm{ppm}$ & $9.92 \mathrm{~b}$ & $10.92 \mathrm{~b}$ & $11.92 \mathrm{~b}$ & $13.92 \mathrm{~b}$ & $14.92 \mathrm{~b}$ & $15.92 \mathrm{~b}$ \\
$500 \mathrm{ppm}$ & $7.88 \mathrm{c}$ & $8.88 \mathrm{c}$ & $9.88 \mathrm{c}$ & $11.88 \mathrm{c}$ & $12.88 \mathrm{c}$ & $13.88 \mathrm{c}$ \\
$750 \mathrm{ppm}$ & $4.88 \mathrm{~d}$ & $5.88 \mathrm{~d}$ & $6.88 \mathrm{~d}$ & $8.88 \mathrm{~d}$ & $9.88 \mathrm{~d}$ & $10.88 \mathrm{~d}$ \\
$1000 \mathrm{ppm}$ & $1.88 \mathrm{e}$ & $2.88 \mathrm{e}$ & $3.88 \mathrm{e}$ & $5.88 \mathrm{e}$ & $6.88 \mathrm{e}$ & $7.88 \mathrm{e}$ \\
\hline
\end{tabular}

It was determined that the number of male flowers increased depending on the increased $\mathrm{AgNO}_{3}$ doses applied
Tab. 6. The number of female flowers of the $\mathrm{AgNO}_{3}$ applied 'GND2' variety in the spring season

\begin{tabular}{ccccccc}
\hline $\begin{array}{c}\text { The applied } \\
\text { silver } \\
\text { nitrate } \\
\text { amounts } \\
\text { (ppm) }\end{array}$ & $\begin{array}{c}20 \\
\text { May }\end{array}$ & $\begin{array}{c}27 \\
\text { May }\end{array}$ & $\begin{array}{c}03 \\
\text { June }\end{array}$ & $\begin{array}{c}26 \\
\text { June }\end{array}$ & $\begin{array}{c}03 \\
\text { July }\end{array}$ & $\begin{array}{c}10 \\
\text { July }\end{array}$ \\
\hline $0 \mathrm{ppm}$ & $16.00 \mathrm{a}^{*}$ & $18.00 \mathrm{a}$ & $20.00 \mathrm{a}$ & $23.75 \mathrm{a}$ & $25.50 \mathrm{a}$ & $27.50 \mathrm{a}$ \\
$250 \mathrm{ppm}$ & $15.00 \mathrm{~b}$ & $16.00 \mathrm{~b}$ & $17.00 \mathrm{~b}$ & $19.00 \mathrm{~b}$ & $20.00 \mathrm{~b}$ & $21.00 \mathrm{~b}$ \\
$500 \mathrm{ppm}$ & $13.00 \mathrm{c}$ & $14.00 \mathrm{c}$ & $15.00 \mathrm{c}$ & $16.92 \mathrm{c}$ & $17.92 \mathrm{c}$ & $18.92 \mathrm{c}$ \\
$750 \mathrm{ppm}$ & $10.00 \mathrm{~d}$ & $11.00 \mathrm{~d}$ & $12.00 \mathrm{~d}$ & $14.00 \mathrm{~d}$ & $15.00 \mathrm{~d}$ & $16.00 \mathrm{~d}$ \\
$1000 \mathrm{ppm}$ & $7.00 \mathrm{e}$ & $8.00 \mathrm{e}$ & $9.00 \mathrm{e}$ & $11.00 \mathrm{e}$ & $12.00 \mathrm{e}$ & $13.00 \mathrm{e}$ \\
\hline
\end{tabular}

${ }^{*}$ The differences between values shown with different letters are statistically significant (Duncan multiple comparison test $\mathrm{P}<0.01$ )

Tab. 7. The number of female flowers of the $\mathrm{AgNO}_{3}$ applied 'GND1' variety in the fall season

\begin{tabular}{ccccccc}
\hline $\begin{array}{c}\text { The applied } \\
\text { silver nitrate } \\
\text { amounts (ppm) }\end{array}$ & $\begin{array}{c}22 \\
\text { Oct }\end{array}$ & $\begin{array}{c}29 \\
\text { Oct }\end{array}$ & $\begin{array}{c}05 \\
\text { Nov }\end{array}$ & $\begin{array}{c}28 \\
\text { Nov }\end{array}$ & $\begin{array}{c}05 \\
\text { Dec }\end{array}$ & $\begin{array}{c}12 \\
\text { Dec }\end{array}$ \\
\hline $0 \mathrm{ppm}$ & $8.92 \mathrm{a}^{*}$ & $10.83 \mathrm{a}$ & $12.83 \mathrm{a}$ & $15.83 \mathrm{a}$ & $17.83 \mathrm{a}$ & $19.54 \mathrm{a}$ \\
\hline $250 \mathrm{ppm}$ & $7.92 \mathrm{~b}$ & $8.92 \mathrm{~b}$ & $9.92 \mathrm{~b}$ & $10.92 \mathrm{~b}$ & $11.92 \mathrm{~b}$ & $12.92 \mathrm{~b}$ \\
$500 \mathrm{ppm}$ & $5.88 \mathrm{c}$ & $6.88 \mathrm{c}$ & $7.88 \mathrm{c}$ & $8.88 \mathrm{c}$ & $9.88 \mathrm{c}$ & $10.88 \mathrm{c}$ \\
$750 \mathrm{ppm}$ & $2.88 \mathrm{~d}$ & $3.88 \mathrm{~d}$ & $4.88 \mathrm{~d}$ & $5.88 \mathrm{~d}$ & $6.88 \mathrm{~d}$ & $7.88 \mathrm{~d}$ \\
$1000 \mathrm{ppm}$ & $1.54 \mathrm{e}$ & $2.54 \mathrm{e}$ & $3.54 \mathrm{e}$ & $4.54 \mathrm{e}$ & $4.79 \mathrm{e}$ & $5.17 \mathrm{e}$ \\
\hline
\end{tabular}

${ }^{*}$ The differences between values shown with different letters are statistically significant (Duncan multiple comparison test $\mathrm{P}<0.01$ )

Tab. 8. The number of female flowers of the $\mathrm{AgNO}_{3}$ applied 'GND2' variety in the fall season

\begin{tabular}{ccccccc}
\hline $\begin{array}{c}\text { The applied } \\
\text { silver nitrate } \\
\text { amounts } \\
\text { (ppm) }\end{array}$ & $\begin{array}{c}22 \\
\text { Oct }\end{array}$ & $\begin{array}{c}29 \\
\text { Oct }\end{array}$ & $\begin{array}{c}05 \\
\text { Nov }\end{array}$ & $\begin{array}{c}28 \\
\text { Nov }\end{array}$ & $\begin{array}{c}05 \\
\text { Dec }\end{array}$ & $\begin{array}{c}12 \\
\text { Dec }\end{array}$ \\
\hline $0 \mathrm{ppm}$ & $14.00 \mathrm{a}^{*}$ & $16.00 \mathrm{a}$ & $18.00 \mathrm{a}$ & $20.75 \mathrm{a}$ & $22.50 \mathrm{a}$ & $23.50 \mathrm{a}$ \\
$250 \mathrm{ppm}$ & $13.00 \mathrm{~b}$ & $14.00 \mathrm{~b}$ & $15.00 \mathrm{~b}$ & $16.00 \mathrm{~b}$ & $17.00 \mathrm{~b}$ & $18.00 \mathrm{~b}$ \\
$500 \mathrm{ppm}$ & $11.00 \mathrm{c}$ & $12.00 \mathrm{c}$ & $13.00 \mathrm{c}$ & $14.00 \mathrm{c}$ & $15.00 \mathrm{c}$ & $16.00 \mathrm{c}$ \\
$750 \mathrm{ppm}$ & $8.00 \mathrm{~d}$ & $9.00 \mathrm{~d}$ & $10.00 \mathrm{~d}$ & $11.00 \mathrm{~d}$ & $12.00 \mathrm{~d}$ & $13.00 \mathrm{~d}$ \\
$1000 \mathrm{ppm}$ & $3.50 \mathrm{e}$ & $5.75 \mathrm{e}$ & $6.75 \mathrm{e}$ & $8.00 \mathrm{e}$ & $8.42 \mathrm{e}$ & $8.58 \mathrm{e}$ \\
\hline
\end{tabular}

${ }^{*}$ The differences between values shown with different letters are statistically significant (Duncan multiple comparison test $\mathrm{P}<0.01$ )

to the 'GND1' variety in the fall season, and the differences between those increases were determined to be statistically significant $(\mathrm{P}<0.01)$ (Tab. 3).

It was determined that the number of male flowers again increased depending on the increased $\mathrm{AgNO}_{3}$ doses applied to the 'GND2' variety as happened on the 'GND1' variety in the fall season, and the differences between those applications were determined to be statistically significant at the $1 \%$ level (Tab. 4).

The effect of applied $\mathrm{AgNO}_{3}$ on the number of male flowers on 'GND1' and 'GND2' varieties between seasons was determined to be statistically insignificant level on the 'GND1' variety and significant on the 'GND2' variety $(\mathrm{P}<0.01)$ (Tab. 1, Tab. 2, Tab. 3, Tab. 4). 
142

\section{The Effects of $\mathrm{AgNO}_{3}$ on the number of female flowers}

The female flowers were observed both in the control group and $\mathrm{AgNO}_{3}$ applied plants during both the fall and spring seasons.

The differences between the number of female flowers having applied different $\mathrm{AgNO}_{3}$ doses to the 'GND1' variety in the spring season were determined to be statistically significant $(\mathrm{P}<0.01)$ (Tab. 5).

It was determined that the number of female flowers again decreased depending on the increased $\mathrm{AgNO}_{3}$ doses applied to the 'GND2' variety in the spring season, as happened in the fall season, and the differences between those decreases were determined to be statistically significant $(\mathrm{P}<0.01)$ (Tab. 6).

It was determined that the number of female flowers decreased depending on the increased $\mathrm{AgNO}_{3}$ doses applied to the 'GND1' variety in the fall season, and the differences between those decreases were determined to be statistically significant $(\mathrm{P}<0.01)$ (Tab. 7$)$.

It was determined that the number of female flowers decreased depending on the increased $\mathrm{AgNO}_{3}$ doses applied to the 'GND2' variety in the fall season, and the differences between those decreases were determined to be statistically significant at the $1 \%$ level (Tab. 8).

The effects of applied $\mathrm{AgNO}_{3}$ on the number of male flowers on the 'GND1' and 'GND2' varieties were determined to be statistically significant in terms of differences between seasons $(\mathrm{P}<0.01)$ (Tab. 5, Tab. 6, Tab. 7, Tab. 8).

\section{Discussion}

Since the varieties used in the study are parthenocarpic, the male flowers were observed only on $\mathrm{AgNO}_{3}$ applied plants both in the fall and spring seasons.

It was determined that the number of male flowers also increased depending on the increased $\mathrm{AgNO}_{3}$ doses applied to the 'GND1' variety in the spring season, and the differences between those increases were determined to be statistically significant at the $1 \%$ level. The $\mathrm{AgNO}_{3}$ applications increased the number of male flowers on the 'GND1' variety in the same season at a statistically significant level $(\mathrm{P}<0.01)$.

It was determined that the number of male flowers increased depending on the increased $\mathrm{AgNO}_{3}$ doses applied to the 'GND1' variety in the fall season and the differences between those increases were determined to be statistically significant $(\mathrm{P}<0.01)$. It was determined that the number of male flowers again increased depending on the increased $\mathrm{AgNO}_{3}$ doses applied to the 'GND2' variety, as happened on the 'GND1' variety in the same season, and the differences between those applications were determined to be statistically significant at the $1 \%$ level.

In the measurements, the highest number of male flowers was determined as $1000 \mathrm{ppm}$, and this was followed by doses of 750 ppm, 500 ppm and 250 ppm $\mathrm{AgNO}_{3}$ applications, respectively.

It was determined that the number of male flowers increased depending on the increased $\mathrm{AgNO}_{3}$ doses applied to the 'GND1' and 'GND2' varieties in the fall and spring seasons, and the differences between those increases were determined to be statistically significant $(\mathrm{P}<0.01)$. This situation complies with the findings regarding similar opinions that the $\mathrm{AgNO}_{3}$ applications cause an increase in the number of male flowers in cucumbers (Beyer, 1976; Den Nijs and Visser, 1980; Anonymous, 1987; Robinson and Walters, 1997; Hallidri, 2004).

The effects of applied $\mathrm{AgNO}_{3}$ on the number of male flowers on the 'GND1' and 'GND2' varieties between seasons were determined to be statistically insignificant on the 'GND1' variety and significant on the 'GND2' variety.

In the cucumber plants of the 'GND1' and 'GND2' varieties exposed to silver nitrate applications, the number of male flowers also increased together with the increasing silver nitrate concentration. The increase in the fall planting period was more than the increase in the spring planting period. The greater increase in the number of male flowers during the fall season can be explained by the fact that the planting period was during the warmer months or the length of the days.

Since More and Munger (1986) determined that the light period after the $\mathrm{AgNO}_{3}$ application also affected the formation of male flowers and that the formation of male flowers decreased in the long (15-20 hours) light periods, the results of the aforementioned research are consistent with the results obtained in our study.

In the literature, it has been reported that morphological and physiological changes that occur in plants differ depending on air temperature (Krug and Liebig, 1989; Gosselin and Trudel, 1986; Ney and Turc, 1993; Reath and Wittwer, 1952).

The control plants were in the first ranking in both periods in terms of the obtained number of female flowers. In the silver nitrate applied plants, it was observed that the decrease in the number of female flowers with the increase of the applied $\mathrm{AgNO}_{3}$ doses was statistically significant $(\mathrm{P}<0.01)$. The planting periods were also found to be effective in this decrease detected in the number of female flowers. Despite the dominant effects of the solutions containing of silver nitrate concentrations, the number of female flowers was greater in the spring planting period compared to the fall planting period.

The result that the determined decrease in the number of female flowers in the 'GND1' and 'GND2' varieties with the increasing doses of $\mathrm{AgNO}_{3}$ in fall and spring was statistically significant $(\mathrm{P}<0.01)$ is consistent with the results of Takahashi and Jaffe's (1984) study intended to determine the role of the hormone-controlled sex formation in cucumbers.

The reason for the decrease in the number of female flowers can be connected to the inhibition of signal production of the internal ethylene responsible for the development of the female flowers by applied $\mathrm{AgNO}_{3}$ in cucumber plants. Prodanovic and Stankovic (2002), who performed research similar to this study with the purpose of identifying the possibilities of optimal sex changes, investigated the effectiveness of silver nitrate solutions ap- 
plied in different concentrations $(0.01 \%, 0.02 \%, 0.03 \%$, $0.04 \%$ ) and planting seasons (spring, summer) for the determination of gender in two kinds of cucumbers in their study. They identified that the number of male flowers increased as the silver nitrate concentration increased, and that this increase was more significant in the first planting season than the second planting season; that the silver nitrate decreased the number of female flowers compared to the control group in both of the planting seasons; that the optimal sex change was achieved with $0.02 \%$ silver nitrate solution, while this effect was occurring with $0.03 \%$ silver nitrate solution in the period with a longer daylight period. In addition, the researchers concluded that the sex determination within the limits determined by genotype was affected by environmental conditions; that the internal ethylene responsible for the determination of female sex in the gynoecious cucumber varieties is blocked by the $\mathrm{Ag}^{+}$ion effect (ethylene action blocker) and that the silver ions cause the male flower development; that the silver nitrate application needs to be observed in the seed production and selection processes of gynoecious cucumber varieties; that the silver to obtain male flowers can mask the sex; that some plants, which will serve as pollen donors, can be treated with silver nitrate in this study.

The silver nitrate application did not lead to the formation of hermaphrodite flowers having both male and female characteristics in cucumber varieties in both cultivation periods.

In this study, similar to Hallidri's study (2004), the effects of the silver nitrate concentration were examined in determining the gender in parthenocarpic and gynoecious cucumbers; it was observed that the formations of male flowers were connected to the silver nitrate concentrations; that the silver nitrate applications with low concentrations were insufficient to engender male flowers; that the highest number of male flowers were observed on the plants sprayed with $1000 \mathrm{ppm}$ silver nitrate solutions; that the weak plants recovered within 7 to 10 days after they had been sprayed with 750 and 1000 ppm silver nitrate solutions.

The research, which was intended to quantify the effects of different concentrations of silver nitrate applications and planting periods in the determination of sex of the 'GND1' and 'GND2' varieties having the $\mathrm{AgNO}_{3}$ applications in both plantings periods, shows the importance of the determination of appropriate silver nitrate doses.

This research can be applied to the large-scale commercial seed production of gynoecious $\mathrm{x}$ gynoecious cucumber hybrids by selecting the most appropriate silver nitrate concentrations and by obtaining male parents that will be used as the pollen sources from gynoecious types appro-

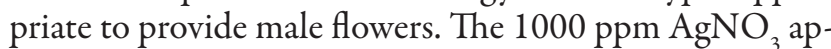
plication is recommended considering the number of male flowers in the cases when it will be used in the production of $\mathrm{F}_{1}$ cucumber seeds. In light of the results obtained, this research has proved to be guidance to develop practical recommendations on the basis of hybrid cucumber seeds production and for subsequent studies.

\section{References}

Anonymous (1987). Hybrid seed production of selected cereal oil and vegetable crops. FAO Plant Production and Protection, pp. 82.

Apan H (1974). The researches on the effects of 2-Chloroethylphosphonic acid (Ethrel) on the gender appearances and on some other characteristics of cucumbers. Faculty of Agriculture Publications No. 165, Research Series No. 99, Erzurum.

Beyer EM, Jr. (1976). Silver ion: a potent antiethylene agent in cucumber and tomato. HortSci 11(3):195-196.

Cantliffe DJ (1981). Alteration of sex expression in cucumber due to changes in temperature light intensity and photoperiod. J Amer Soc Horti Sci 106:133-136.

Den Nijs APM, Visser DL (1980). Induction of male flowering in gynoecious cucumbers (Cucumis sativus L.) by silver ions. Euphytica 29(2):273-280.

Frankel R, Glun E (1977). Pollination Mechanisms, Reproduction and Plant Breeding. Springer, Verlag, Berlin.

Gosselin A, Trudel MJ (1986). Root-zone temperature effects on pepper. J Amer Soc Hort Sci 111(2):220-224.

Hallidri M (2004). Effect of silver nitrate on induction of staminate flowers in gynoecious cucumber line (Cucumis sativus L.). Acta Horticulturae 637, XXVI International Horticultural Congress, Advances in Vegetable Breeding.

Krug H, Liebig HP (1989). Production planning-transplant period (Emergence to transplant size). Acta Hort 248:175180.

More TA, Munger HM (1986). Gynoecious sex expression and stability in cucumber (Cucumis sativus L.). Euphytica 35(3):899-903.

Ney B, Turc O (1993). Heat-unit-based description of the reproductive development of peas. Crop Sci 33:510-514.

Prodanovic S, Stankovic L (2002). Silver nitrate effects on sex expression in cucumbers. Proc of the Second Balkan Sympos Vegetables and Potatoes. Acta Hort 579:202-207.

Reath AN, Wittwer SH (1952). The effects of temperature and photoperiod on the development of pea varieties. Proc Amer Soc Hort Sci 60:301-310.

Robinson RW, Walters DS (1997). Cucurbitas. CAB International, Cambridge, 226p.

Şensoy AS (2004). Investigation on the inheritance characteristics of fruit's shell colour of Summer Squash (Cucurbita pepo L.) plants and research on storing the pollens to be used for rehabilitation programs. Akdeniz University, Institute of ScienceMsc. Thesis, pp. 62, Antalya.

Takahashi H, Jaffe MJ (1984). Further studies of auxin and ACC induced feminization in the cucumber plant using ethylene inhibitors. Phyton 44(1):81-6.

Vural H, Eşiyok D, Duman I (2000). Culture vegetables (Vegetable Production). Ege University, Faculty of Agriculture, Department of Horticulture, Ege University Printing House, Izmir. 